pelige kriterier. Prioritering ut fra et et kortsiktig ønske om å spare penger vil i lengden kaste lite av seg.

\section{Trygve Holmøy}

Nevrologisk avdeling

Akershus universitetssykehus

Trygve Holmøy (f. 1960) er spesialist i nevrologi og overlege ved Nevrologisk avdeling. Ingen oppgitte interessekonflikter.

\section{Litteratur}

1. Raknes G, Giverhaug T. Naltrekson - høye forventninger til lave doser. Tidsskr Nor Legeforen 2011; 131: $844-6$.

2. Holmøy T, Celius EG. Utvikling av ny behandling for multippel sklerose. Tidsskr Nor Legeforen 2011. 131: $832-6$.

3. Zagon IS, Rahn KA, Turel AP et al. Endogenous opioids regulate expression of experimental autoimmune encephalomyelitis. A new paradigm for he treatment of multiple sclerosis. Exp Biol Med 2009; 234: 1383-92.

\section{Behandle oss som eldre piloter!}

I Tidsskriftet nr. 8/2011 tar Lars Tjensvoll for seg temaet eldre leger og lisens (1) etter at det har vært debatt om dette i Tidsskriftet i lengre tid (2-6). Etter hans mening bør det av forsvarlighetshensyn være en øvre aldersgrense for legers autorisasjon - slik det for eksempel er for piloter og yrkessjåfører og bilførere generelt. Han hevder at veitrafikkloven stopper yrkessjåfører når de er 75 år. Deretter må de ha legeattest. Vanlige bilførere må ha helseattest etter fylte 70 år. Piloter og flygeledere stoppes når de er 65 år uansett helsetilstand. Så føyer han til: Hva gjør leger annerledes enn disse?

Nå er det bare slik at:

- yrkessjåførene mister ikke førerkortet sitt

- piloter mister ikke flysertifikatet sitt, de kan fortsatt fly så mye de lyster - til privat bruk

- den vanlige bilfører får beholde sitt førerkort etter «bestått» legesjekk

Akk ja, hadde vi bare blitt behandlet som disse! Lars Tjensvoll hevder det er naturlig at vi leger mister autorisasjonen når vi blir 75 år, men at vi unntaksvis kan få lisens til fortsatt praksis forutsatt at vi ikke lider av demens, nevrologisk sykdom, symptomgivende kreft, psykiatrisk sykdom, synsforstyrrelse og annet som kan påvirke vår vurderingsevne (en utenkelig tilstand hos leger under 75 år).

Jeg gikk innom et apotek for å be om $8 \mathrm{ml}$ Sofradex øredråper. Det var tre dager etter jeg hadde fylt 75 år. Med klar røst ble jeg gjort oppmerksom på at jeg var fratatt min autorisasjon, så de kunne dessverre ikke hjelpe meg. 18. mars var jeg fullt tilregnelig, uten demens, psykiatrisk sykdom, symptomgivende kreft, nevrologisk sykdom eller synsforstyrrelse. To dager etter tilhørte jeg tydeligvis minst én av disse kategoriene. Jeg ble nemlig 75 år 19. mars.
For ordens skyld: Dette angår ikke retten til å kunne drive praksis med tilskudd eller å være ansatt på institusjon ol. Dette handler om retten til å kunne ta ut medisiner til eget bruk. Slik det til privat bruk er tillatt for pilotene å kjøre fly og yrkessjåførene å kjøre bil.

\section{Einar Skatteboe}

Bærum

Einar Skatteboe (f. 1936) er spesialist i samfunnsmedisin og pensjonert lege. Ingen oppgitte interessekonflikter.

\section{Litteratur}

1. Tjensvoll L. Eldre piloter, yrkessjåfører - og leger. Tidsskr Nor Legeforen 2011; 131: 803

2. Hagen S. Samfunnets hån mot eldre leger. Tidsskr Nor Legeforen 2009: 129: 311-12.

3. Aasland OG, Bringedal B, Ronge K. Aldersgrense for legers autorisasjon og lisens. Tidsskr Nor Legeforen 2010; 130: 1917-20.

4. Bruusgaard D. Forsvarlighet og autorisasjon Tidsskr Nor Legeforen 2010; 130: 1906.

5. Janbu T. Eldre leger og lisens. Tidsskr Nor Legeforen 2011; 131: 111

6. Hagen S. Hvor er Legeforeningen? Tidsskr Nor Legeforen 2011; 131: 13-4.

\section{På kant med Kant?}

I Tidsskriftet nr. 11/2011 (1) antyder filosofiprofessor Jens Saugstad ved Universitetet i Oslo at vår forskningsgruppe i en artikkel i Science (2) og i en popularisert omtale av denne i Tidsskriftet (3) ikke viser respekt for andre fag. Vi beklager at han føler det slik. Vi har ikke skrevet våre vitenskapelige arbeider med den hensikt å fornærme enkeltpersoner eller et helt fagfelt.

Vi blir kritisert for vår henvisning til filosofen Immanuel Kants skrifter i forbindelse med resultater som tyder på et medfødt grunnlag for stedsans. Saugstad refererer til vår artikkel i Science, der vi brukte nevrofysiologiske metoder til å studere utviklingen av hjernens navigasjonssystemer (2). I innledningen til artikkelen står det en henvisning til Kant: «it has remained unclear whether rat pups form any representation of the local environment at the onset of outbound exploration, (...) as would be expected if the spatial representation system is preconfigured» (2). I det siste setningsleddet refereres det til Kant.

Her kan det være nyttig med en avklaring av terminologi. Den siterte setningen sier at spatiale representasjoner er prekonfigurerte. Dette betyr ikke at disse representasjonene er medfødte; det betyr bare at de er til stede før rotten begynner å utforske et spatialt miljø for første gang, helt i tråd med Kants ideer. I prinsippet kan de være et resultat av tidlig modning eller læring. Saugstad antar videre at vi med representasjon mener det samme som Kant. Imidlertid brukes representasjon i nevrobiologi om all nevral aktivitet som uttrykker egenskaper ved omverdenen. Det har ingenting å gjøre med hva rotten eventuelt skulle forestille seg subjektivt. Når det gjelder den populariserte omtalen i Tidsskriftet (3), kan vi være enig $i$ at referansen til medfødte egenskaper var upresis, selv om formålet var å forenkle. Det kan i tillegg være verdt å notere seg at Science-artikkelen ledsages av en kommentarartikkel skrevet av Kant-eksperten Linda Palmer, der hun diskuterer sammenhengen mellom våre empiriske funn $\mathrm{og}$ Kants filosofi (4). Artikkelen hennes ender slik: «Kant believed he had established the a priori (and not merely innate) status of space as a «transcendental condition» of our representation of the world. This is, however, quite compatible with the existence of a neurobiological substrate of the mental functions he identifies, so he would likely be fascinated and delighted by these investigations» (4).

Filosofiske diskusjoner bidrar til akademisk kunnskapsutvikling, og vi håper at denne diskusjonen også vil bidra.

\section{Tale Litleré Bjerknes}

May-Britt Moser

Norges teknisk-naturvitenskapelige universitet

Tale Litleré Bjerknes (f. 1989) er medisinstudent ved Norges teknisk-naturvitenskapelige universitet.

Ingen oppgitte interessekonflikter.

May-Britt Moser (f. 1963) er psykolog og professor i nevrovitenskap ved Kavli-instituttet og Senter for hukommelsesbiologi, Norges teknisk-naturvitenskapelige universitet. Ingen oppgitte interessekonflikter.

Litteratur

1. Saugstad J. Galt om Kant. Tidsskr Nor Legeforen 2011; 131: 1072

2. Langston RF, Ainge $J$ et al. Development of the spatial representation system in the rat. Science 2010; 328: 1576-80

3. Hem E. Kartlegging av hjernens navigasjonssystemer. Tidsskr Nor Legeforen 2011; 131: 654

4. Palmer L, Lynch $G$. A Kantian view of space. Science 2010; 328: 1487-8.

\section{RETTELSE}

Rettferdig tilgang til traumeforskning.

Marius Rehn, Hans Morten Lossius

Tidsskr Nor Legeforen 2011; 131: 669

I Tidsskriftet nr. 7/2011 s. 669 skulle det i denne kommentaren under oppgitte interessekonflikter stått:

Oppgitte interessekonflikter: Forfatterne er ansatt i Stiftelsen Norsk Luftambulanse, som finansierer og garanterer økonomisk for Scandinavian Journal of Trauma, Resuscitation and Emergency Medicine. Hans Morten Lossius er redaktør i dette tidsskriftet. 